ҚАЗАҚСТАН РЕСПУБЛИКАСЫ

ҰЛТТЫҚ ҒЫЛЫМ АКАДЕМИЯСЫНЫҢ

Абай атындағы Қазақ ұлттық педагогикалық университетінің
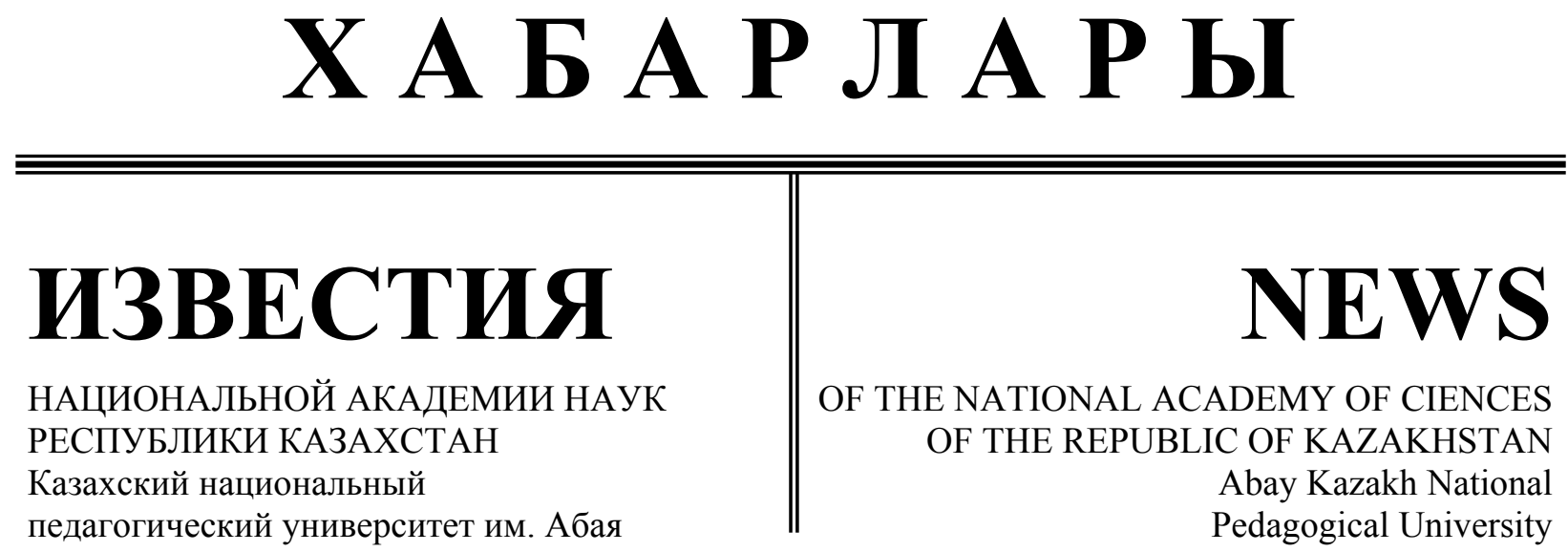

\author{
SERIES \\ OF SOCIAL AND HUMAN SCIENCES
}

2 (330)

MARCH - APRIL 2020

PUBLISHED SINCE JANUARY 1962

PUBLISHED 6 TIMES A YEAR 
Бас редактор

ҚР ҰҒА құрметті мүшесі

Балықбаев Т.O.

Р ед акция а лқ а сы:

экон. ғ. докторы, проф., ҚР ҰҒА академигі Баймұратов У.Б.; филос. ғ.докторы, проф., ҚР ҰҒА академигі Есім Г.Е.; фил. ғ. докторы,, проф., ҚР ҰҒА академигі Қирабаев С.С.; эк. ғ. докторы, проф., ҚР ҰҒА академигі Қошанов А.К.; эк.ғ. докторы, проф., ҚР ҰҒА академигі Нәрібаев К.Н. (бас редактордың орынбасары); филос. ғ.докторы, проф., ҚР ҰҒА академигі Нысанбаев А.Н.; заң ғ. докторы, проф., ҚР ҰҒА академигі Сәбікенов С.Н.; заң ғ. докторы, проф., ҚР ҰҒА академигі Сүлейменов М.К.; эк. ғ. докторы, проф., ҚР ҰҒА академигі Сатыбалдин С.С.; тарих ғ. докторы, проф., ҚР ҰҒА академик Әбжанов Х.М.; тарих ғ. докторы, проф., ҚР ҰҒА корр. мүшесі Әбусеитова М.Х.; тарих ғ. докторы, проф., ҚР ҰҒА академик Байтанаев Б.А.; филол. Ғ. докторы, проф., ҚР ҰҒА корр. мүшесі Жақып Б.А.; фил. ғ. докторы, проф., академик НАН РК Қалижанов У.К.; филол. ғ. докторы, проф., ҚР ҰҒА академик Қамзабекұлы Д.; тарих ғ. докторы, проф., ҚР ҰҒА академик Қожамжарова Д.П.; тарих ғ. док-торы, проф., ҚР ҰҒА академик Қойгелдиев М.К.; фил. ғ. докторы, проф., ҚР ҰҒА корр. мүшесі Құрманбайұлы Ш.; тарих ғ. докторы, проф., ҚР ҰҒА корр. мүшесі Таймағанбетов Ж.К.; социол. ғ. докторы, проф., ҚР ҰҒА корр. мүшесі Шәукенова 3.К.; фил. ғ. докторы, проф., ҚР ҰҒА корр. мүшесі Дербісәлі А.; саяси. ғ. докторы, проф., Бижанов А.К., тарих ғ. докторы, проф., Кабульдинов 3.Е.; фил. ғ. докторы, проф., ҚР ҰҒА корр мүшесі Қажыбек Е.3.

Р еда ц ия ке н е с і:

Молдова Республикасының ҰҒА академигі Белостечник Г. (Молдова); Әзірбайжан ҰҒА академигі Велиханлы Н. (Азербайджан); Тәжікстан ҰҒА академигі Назаров Т.Н. (Тәжікстан); Молдова Республикасының ҰҒА академигі Рошка А. (Молдова); Молдова Республикасының ҰҒА академигі Руснак Г. (Молдова); Әзірбайжан ҰҒА корр. мүшесі Мурадов Ш. (Әзірбайжан); Әзірбайжан ҰҒА корр. мүшесі Сафарова 3. (Әзірбайжан); э. ғ. д., проф. Василенко В.Н. (Украина); заң ғ. докт., проф. Устименко В.А. (Украина)

«Қазақстан Республикасы Ұлттық ғылым академиясының Хабарлары. Қоғамдық және гуманитарлық ғылымдар сериясы».

ISSN 2224-5294

Меншіктенуші: «Қазақстан Республикасының Ұлттық ғылым академиясы» РҚБ (Алматы қ.)

Қазақстан республикасының Мәдениет пен ақпарат министрлігінің Ақпарат және мұрағат комитетінде 30.04.2010 ж. берілген № 10894-Ж мерзімдік басылым тіркеуіне қойылу туралы куәлік

Мерзімділігі: жылына 6 рет.

Тиражы: 500 дана.

Редакцияның мекенжайы: 050010, Алматы қ., Шевченко көш., 28; 219, 220 бөл.; тел.: 272-13-19, 272-13-18 http://soc-human.kz/index.php/en/arhiv

(C) Қазақстан Республикасының Ұлттық ғылым академиясы, 2020

Типографияның мекенжайы: «NurNaz GRACE», Алматы қ., Рысқұлов көш., 103. 
Главный редактор

Почетный член НАН РК

T.O. Балыкбаев

Р едакционнная коллегия:

докт. экон. Н., проф., академик НАН РК У.Б. Баймуратов; докт. филос. н., проф., академик НАН РК Г.Е. Есим; докт. фил. Н., проф., академик НАН РК С.С. Кирабаев; докт. экон. Н., проф., академик НАН РК А.К. Кошанов; докт. экон. Н., проф., академик НАН РК К.Н. Нарибаев (заместитель главного редактора); докт. филос. н., проф., академик НАН РК А.Н. Нысанбаев; докт. юр. Н., проф., академик НАН РК С.Н. Саби-кенов; докт. юр. Н., проф., академик НАН РК М.К. Сулейменов; докт. экон. Н., проф., академик НАН РК С.С. Сатубалдин; докт. ист. н., проф., академик НАН РК Х.М. Абжанов; докт. ист. н., проф., чл.-корр. НАН РК М.Х. Абусеитова; докт. ист. Н., проф., академик НАН РК Б.А. Бай-танаев; докт. фил. н., проф., чл.-корр. НАН РК Б.А. Жакып; докт. фиолол. н., проф., академик НАН РК У.К. Калижанов; докт. фил. н., проф., академик НАН РК Д. Камзабекулы; докт. ист. н., проф., академик НАН РК Д.П. Кожамжарова; докт. ист. Н., проф., академик НАН РК М.К. Кой-гельдиев; докт. филол. н., проф., чл.-корр. НАН РК Ш. Курманбайулы; докт. ист. Н., проф., чл.-корр. НАН РК Ж.К. Таймаганбетов; докт. социол. н., проф., чл.-корр. НАН РК З.К. Шаукенова; д. филол. н., проф., чл.-корр. НАН РК А. Дербисали; доктор политических наук, проф., Бижанов А.К.; доктор ист. наук, проф., Кабульдинов 3.Е.; доктор филол. н., проф., член-корр. НАН РК Қажыбек Е.3.

$$
\text { Р е дакци онны й со в е т }
$$

академик НАН Республики Молдова Г. Белостечник (Молдова); академик НАН Азербайджанской Республики Н. Велиханлы (Азербайджан); академик НАН Республики Таджикистан Т.Н. Назаров (Таджикистан); академик НАН Республики Молдова А. Рошка (Молдова); академик НАН Республики Молдова Г. Руснак (Молдова); чл.-корр. НАН Азербайджанской Республики Ш. Мурадов (Азербайджан), член-корр. НАН Азербайджанской Республики 3.Сафарова (Азербайджан); д. э. н., проф. В.Н. Василенко (Украина); д.ю.н., проф. В.А. Устименко (Украина)

Известия Национальной академии наук Республики Казахстан. Серия общественных и гумани-тарных наук.

ISSN 2224-5294

Собственник: РОО «Национальная академия наук Республики Казахстан» (г. Алматы)

Свидетельство о постановке на учет периодического печатного издания в Комитете информации и архивов Министерства культуры и информации Республики Казахстан № 10894-Ж, выданное 30.04.2010 г.

Периодичность 6 раз в год

Тираж: 500 экземпляров

Адрес редакции: 050010, г. Алматы, ул. Шевченко, 28; ком. 219, 220; тел. 272-13-19, 272-13-18

http://soc-human.kz/index.php/en/arhiv 
Chief Editor

Honorary member of NAS RK

Balykbayev T.O

Editorial board:

Doctor of economics, prof, academician of NAS RK Baimuratov U.B.; doctor of philosophy, prof, academician of NAS RK Esim G.E.; doctor of philology, prof, academician of NAS RK Kirabayev S.S.; doctor of economics, prof, academician of NAS RK Koshanov A.K.; doctor of economics, prof, academician of NAS RK Naribayev K.N. (deputy editor-in-chief); doctor of philosophy, prof, academician of NAS RK Nyssanbayev A.N.; doctor of law, prof, academician of NAS RK Sabikenov S.N.; doctor of law, prof, academician of NAS RK Suleymenov M.K.; doctor of economy, prof, academician of NAS RK Satybaldin S.S.; doctor of history, prof, academician of NAS RK Abzhanov H.M; doctor of history, prof, corresponding member of NAS RK Abuseitova M.H.; doctor of history, prof, academician of NAS RK Baitanaev B.A.; doctor of philology, prof, corresponding member of NAS RK Zhakyp B.A.; doctor of philology, prof, academician of NAS RK Kalizhanov U.K.; doctor of philology, prof, academician of NAS RK Hamzabekuly D.; doctor of history, prof, academician of NAS RK Kozhamzharova D.P.; doctor of history, prof, academician of NAS RK Koigeldiev M.K.; doctor of philology, prof, corresponding member of NAS RK Kurmanbaiuly Sh.; doctor of history, prof, academician of NAS RK Taimaganbetov J.K.; doctor of sociology, prof, corresponding member of NAS RK Shaukenova Z.K.; doctor of philology, prof, corresponding member of NAS RK Derbisali A.; doctor of political science, prof Bizhanov A.K; doctor of History, prof Kabuldinov Z.E.; doctor of philology, prof, corresponding member of NAS RK Kazhybek E.Z.

\section{Editorial staff:}

Academician NAS Republic of Moldova Belostechnik.G (Moldova); Academician NAS Republic of Azerbaijan Velikhanli N. (Azerbaijan); Academician NAS Republic of Tajikistan Nazarov T.N. (Tajikistan); Academician NAS Republic of Moldova Roshka A. (Moldova) Academician NAS Republic of Moldova Rusnak G. (Moldova); Corresponding member of the NAS Republic of Azerbaijan Muradov Sh. (Azerbaijan); Corresponding member of the NAS Republic of Azerbaijan Safarova Z. (Azerbaijan); Associate professor of Economics Vasilenko V.N. (Ukraine), Associate professor of Law Ustimenko V.A. (Ukraine)

News of the National Academy of Sciences of the Republic of Kazakhstan. Series of Social and Humanities. ISSN 2224-5294

Owner: RPA "National Academy of Sciences of the Republic of Kazakhstan" (Almaty)

The certificate of registration of a periodic printed publication in the Committee of information and archives of the Ministry of culture and information of the Republic of Kazakhstan N 10894-Ж, issued 30.04.2010

Periodicity: 6 times a year

Circulation: 500 copies

Editorial address: 28, Shevchenko str., of. 219, 220, Almaty, 050010, tel. 272-13-19, 272-13-18

http://soc-human.kz/index.php/en/arhiv

(C) National Academy of Sciences of the Republic of Kazakhstan, 2020

Address of printing house: «NurNaz GRACE», 103, Ryskulov str, Almaty. 
N E W S

OF THE NATIONAL ACADEMY OF SCIENCES OF THE REPUBLIC OF KAZAKHSTAN

SERIES OF SOCIAL AND HUMAN SCIENCES

ISSN 2224-5294

Volume 2, Number 330 (2020), $160-165$

https://doi.org/10.32014/2020.2224-5294.51

UDC 004

МРНТИ 00.29

\author{
Sh.A. Naubetova ${ }^{1}$, A.I. Tuganbayev ${ }^{1}$, \\ J.Sh. Uzdenbaev ${ }^{2}$, A.J. Ayaganova ${ }^{1}$, R.N. Kantayeva ${ }^{1}$ \\ ${ }^{1}$ Academy of economics and law named after U.A. Dzholdasbekov, Taldykorgan, Kazakhstan; \\ ${ }^{2}$ Zhetysu State University n.a. I. Zhansugurov, Taldykorgan, Kazakhstan. \\ E-mail: Shuga.naubetova@bk.ru; arman.tuganbayev@bk.ru; Jorajorin@mail.ru; \\ Ayazhanayaganova@mail.ru; ramziya.kantayeva@bk.ru
}

\title{
DESIGN FEATURES OF ELECTRONIC EDUCATIONAL RESOURCES
}

\begin{abstract}
The constant changes taking place in the life of the modern information society must find an adequate and immediate reflection, both in the educational process itself and in various educational materials. One of the possible solutions to this situation may be the development of electronic training tools for almost all disciplines and their publication in the world's telecommunications networks or on information carriers that provide an opportunity for simple rapid replication. This statement is based, first of all, on the possibility of dynamic changes and additions to the content of electronic learning tools in accordance with current changes in society, science, culture, etc.in Addition, the practical work of students with information presented in electronic form will play a positive role in the General familiarization of future specialists with computer and telecommunications technologies. The rapid development of information technologies has caused a wave of interest in computer training, but the quality and effectiveness of the training programs developed remains at a low level. For example, according to American experts, more than $80 \%$ of training programs do not meet the pedagogical requirements. According to other data, as evidenced by foreign and domestic pedagogical research, $90 \%$ of the developed software tools for education are unsuitable for use due to their non-compliance with the psychological and pedagogical requirements, etc. It should be noted that the quality of educational software products developed by various commercial firms is poor. For example, in Germany, only 80 out of 4000 software tools, i.e. only $2 \%$ meet the minimum quality criteria. It is difficult to imagine the modern educational process without high-quality provision of educational electronic materials. In recent years, their species composition has been supplemented by the latest pedagogical software tools, such as electronic textbooks, computer modeling tools, Internet sites, simulators, training programs and other educational resources.

The article considers the importance of the effectiveness of the use of electronic educational resources in the field of education and science of the Republic of Kazakhstan. An electronic educational resource (EOR) is a learning tool that helps the teacher in conducting classes on the appropriate course or completely replaces its activities. It is possible to use such a complex for the organization of independent work of students on the study of theoretical material, for the organization of practical and seminar classes, control and self-control. An EOR is created for a specific course in accordance with the requirements of the state educational standard. It can include a variety of software tools, ranging from text documents with illustrative material and hyperlinks, to emulators of laboratory installations. In the most General case, electronic educational resources include educational videos and sound recordings, which can be played using a household tape recorder or CD player. The most up-to-date and effective electronic educational resources in the field of use in the educational process are reproduced on a computer. Therefore, the content of this distance course is devoted to the description of the essential characteristics and possibilities of using the above resources in the General education system. The principal difference between electronic educational resources and digital educational resources (DSS) is the presence of an interactivity component in the first case. Such a complex is most often used for distance learning, but can be implemented in standard forms of training: full-time, evening, correspondence, external studies.

The article examines the problems of using information technologies in the educational process. The characteristic of an electronic educational resource that is a means of training that helps the teacher in conducting classes on the appropriate course or completely replaces its activities is given. Such a complex can be used for
\end{abstract}


organizing independent work of students on the study of theoretical material, for organizing practical and seminar classes, control and self-control. The article describes a generalized approach to designing the content of electronic educational resources (EOR), based on the formation of a unified methodology for teaching special disciplines, with a wide use of modern information technologies. The article analyzes the results of the implementation of the author's program of professional development of employees of the education system, which has a practical focus on the requests of teachers for the design and development of author's e-learning projects and the formation of a regional information and educational environment of a multifunctional virtual community of professional teachers.

Keywords: electronic educational resources, designing e-learning resources, content formation, visualization of the content objects, education, information.

\section{INTRODUCTION}

Currently, there are many techniques for developing e-learning resources (ESM), which as a rule contain General guidelines for building the structure of the e-course, i.e., are Advisory in nature. "Information and communication technologies in education [1]. Terms and definitions" introduces a definition of the ESM: "The electronic educational resource means an educational resource, represented in digital form and which includes structure, subject content, and metadata about them, as well as data, information, software, necessary for its use in the educational process"[2]. In the Guest there are the following types of training: electronics, mobile, network, independent, mixed, joint. Additionally the concept of "educational content", which refers to a structured subject content used in the educational process [3]. In e-learning educational content is the basis of electronic educational resources [4].

Electronic learning resources of various kinds, completeness and applicability in the educational process can take the following forms (from the experience of development and implementation in universities of Kazakhstan) [5]:

- lecture notes;

- teaching aid;

- a guide for laboratory practical work;

- a tutorial on the cycle of practical seminars [6];

- presentations (slide-lectures, lectures and practical presentations, etc.);

- methodological support and materials for independent work [7]; [8];

- organizational-methodical instructions on studying of discipline (usually duplicated in paper form)

- test materials, test questions etc. (Development tool for distance learning courses. (2019). http://www.ict.edu.ru/).

The combination of all these materials and their implementation in the same style can be converted to electronic educational-methodical complex [9].

Some experience in creating e-learning resources is reflected in the works of L.H. Zainutdinova, A.V. Solovova, A.V. Aspen, I.P. Norenkov, V.V. Gura etc.

\section{METHODOLOGY}

In the process of the study were used General methods of research: methods of analysis of the educational process: horizontal, vertical, ratio, comparison, and other.

To study the principles of design of electronic educational resources were used General scientific and special research methods:

- review of the regulatory framework;

- analytical method;

- observation;

- learning experience;

- pedagogical experiment and etc.

\section{RESULTS}

The quality of training include the following basic concepts:

- technical knowledge - knowledge that provides the graduates the basic skill level of knowledge in the specialty [10];

- functional knowledge - knowledge that gives understanding of policies, procedures, practices and functional linkages, which have a significant effect on the efficiency of production systems as a whole [11]; 
- technical aptitude - ability arising on the background of the universal (such as individual psychological characteristics), ensuring successful execution of engineering activities;

- type of thinking - a kind of constructive thinking with the peculiarities caused by the nature of the activities in the presence of productive, cognitive, analytical, logical, creative types of thinking as its individual characteristics;

- the thinking person - a person possessing a certain type of thinking and formed in the process of preparing the personal qualities that allow her professionally implemented in the industrial control system;

- professionalism - the ability to implement professional readiness in a particular specialty on the level of competence acquired by the person in the course of professional activity and brought to perfection [12].

With these requirements in the analysis phase, needs to undertake the following tasks:

- systematization of basic missing knowledge;

- evaluation of the adequacy of depth of assimilation of materials from introductory disciplines of integration of knowledge of disciplines of cycle GED (general studies) in a cycle of SD (selective discipline) [13];

- the diversity and complexity of interdisciplinary relations;

- use the experience of other universities in teaching subjects cycle of SD.

\section{CONCLUSIONS}

Modern information technologies in some cases, reduce the time of creation of electronic educational resources compared to traditional educational resources, at the same time significantly extending their life cycle thanks to the possibility of making additions and changes not only in the process of developing e-learning resources, but also in their application in the educational process.

This approach does not contradict previously developed concepts, but expands and complements the methods of working with content and also takes into account modern tendencies of formation of competence, the impact of international and emerging standards of e-learning. The proposed concept of training content is not dependent on the selection conditions of the environment (shell) of the ESM, it is quite versatile and allows to form in the later stages of development of pedagogical scenarios for any type of training.

Effectively developed electronic educational resources include five elements:

1. The display of information;

2. Guidance on what to do;

3. Exercises for understanding and memorization;

4. Assessment to determine the need to repeat or move to the next step;

5. Interactivity.

The principles of efficiency of electronic educational resources

\begin{tabular}{|l|l|}
\hline \multicolumn{1}{|c|}{ Principles } & \multicolumn{1}{c|}{ Description } \\
\hline Multimedia & Training with the use of text and graphics is better than using only text \\
\hline Spatial relationship & $\begin{array}{l}\text { While teaching, accompanied by text and graphics is better when corresponding text and } \\
\text { graphics are placed next to each other }\end{array}$ \\
\hline Temporary link & $\begin{array}{l}\text { While teaching, accompanied by text and graphics is better when corresponding text and } \\
\text { graphics are displayed simultaneously, not one after another }\end{array}$ \\
\hline Consistency & When training it is better if the text, graphics, or sound is not redundant. \\
\hline Modality & $\begin{array}{l}\text { When learning is better when animation is accompanied by narration than animation } \\
\text { accompanied by onscreen text. }\end{array}$ \\
\hline Redundancy & $\begin{array}{l}\text { When learning is better when animation is accompanied by narration than if the } \\
\text { animation is accompanied by narration and on-screen text. }\end{array}$ \\
\hline Individual differences & $\begin{array}{l}\text { The effect of these principles more strongly expressed when learning the initial } \\
\text { knowledge than the knowledge of a high level, and for very remote students than for } \\
\text { geographically remote little }\end{array}$ \\
\hline
\end{tabular}

Note: compiled by the authors according to the results of the study.

These five elements can be embedded in e-learning or used in combination of blended learning. Despite the fact that almost all of these items can be implemented without the use of media, multimedia 
makes them more effective and meaningful. Giving a person the opportunity to perceive the video and audio media has an advantage over each of these possibilities separately (table). In addition, since the two channels for processing different information, their combination into multimedia is very successful because it uses the advantages of both systems. The connection between text and graphics potentially allow for deeper understanding and better to build a mental model.

\author{
Ш.А. Наубетова ${ }^{1}$, А.И. Туганбаев ${ }^{1}$, \\ Ж.Ш. Узденбаев ${ }^{2}$, А.Ж. Аяганова ${ }^{1}$, Р.Н. Кантаева ${ }^{1}$ \\ 1․А. Жолдасбеков атындағы экономика және құқық академиясы, \\ Талдықорған, Қазақстан; \\ 2 I. Жансүгіров атындағы Жетісу мемлекеттік университеті, \\ Талдықорған, Қазақстан
}

\title{
ЭЛЕКТРОНДЫК БІЛІМ БЕРУ РЕСУРСТАРЫН ЖОБАЛАУ ЕРЕКШЕЛІКТЕРІ
}

Аннотация. Қазіргі ақпараттық қоғам өмірінде болып жатқан тұрақты өзгерістер оқу процесінде де, әртүрлі оқу материалдарында да барабар және тез арада көрініс табуы тиіс. Қалыптасқан жағдайдан ықтимал шығулардың бірі - барлық пәндер бойынша электрондық оқыту құралдарын әзірлеу және оларды күрделі емес жедел тираждауға мүмкіндік беретін әлемдік телекоммуникациялық желілерде немесе ақпараттық тасығыштарда жариялау. Бұл бекіту, бірінші кезекте, қоғам өміріндегі, ғылымдағы, мәдениеттегі және т. б. ағымдағы өзгерістерге сәйкес, электрондық оқыту құралдарының мазмұнын динамикалық өзгерту мен толықтыру мүмкіндігіне негізделген. Ақпараттық технологиялардың қарқынды дамуы компьютерлік оқытуға деген қызығушылықтың толқынын тудырды, бірақ әзірленетін оқыту бағдарламаларының сапасы мен тиімділігі төмен деңгейде қалып отыр. Мысалы, америкалық мамандардың мәліметтері бойынша, оқыту бағдарламаларының 80 \%-дан астамы педагогикалық талаптарды қанағаттандырмайды. Басқа деректер бойынша, шетелдік және отандық педагогикалық зерттеулер көрсеткендей, білім беруге арналған әзірленетін бағдарламалық құралдардың 90 \%-ы олардың психологиялық-педагогикалық және басқа талаптарға сәйкес келмеуіне байланысты пайдалануға жарамсыз болып саналады. Әртүрлі коммерциялық фирмалармен әзірленген оқу бағдарламалық өнімдерінің төмен сапасын атап өткен жөн. Мысалы, Германияда 4000 бағдарламалық құралдың тек 80-і ғана, яғни 2 \%-ы ғана ең төменгі сапа өлшемдеріне жауап береді. Заманауи білім беру үдерісін оқу-электронды материалдарымен сапалы қамтамасыз етпей, елестету қиын. Соңғы уақытта олардың түрлік құрамы электрондық оку құралдары, компьютерлік модельдеу құралдары, интернетсайттар, тренажерлер, оқыту бағдарламалары және басқа да білім беру ресурстары сияқты жаңа педагогикалық бағдарламалық құралдармен толықтырылды.

Мақалада Қазақстан Республикасының Білім және ғылым саласындағы электрондық білім беру ресурстарын пайдалану тиімділігінің мәні қарастырылады. Электрондық білім беру ресурсы (ЭБР) оқытушыға тиісті курс бойынша сабақ өткізуге көмектесетін немесе оның қызметін толық алмастыратын оқыту құралы. Теориялық материалдарды зерделеу бойынша оқушылардың өзіндік жұмысын ұйымдастыру үшін, практикалық және семинарлық сабақтарды, бақылау мен өзін-өзі бақылауды ұйымдастыру үшін осындай кешенді қолдануға болады. ЭБР мемлекеттік білім беру стандартының талаптарына сәйкес, белгілі бір курс үшін құрылады. Оның құрамына иллюстрациялық материалдары мен гиперсілтемелері бар мәтіндік құжаттардан бастап, зертханалық қондырғылардың эмуляторларымен аяқталатын әртүрлі бағдарламалық құралдары кіруі мүмкін. Жалпы алғанда, электронды білім беру ресурстарына оку бейнефильмдері мен дыбыс жазбалары жатады, оларды қайта шығару үшін тұрмыстық магнитофон немесе CD-плеер жеткілікті. Білім беру процесінде пайдалану үшін ең заманауи және тиімді электрондық білім беру ресурстары компьютерде ойнатылады. Сондықтан осы қашықтықтан оқыту курсының мазмұны жалпы білім беру жүйесінде жоғарыда көрсетілген ресурстарды қолданудың мәні мен мүмкіндіктерін сипаттауға арналған. Электрондық білім беру ресурстарының сандық білім беру ресурстарынан (ЦБР) принципті айырмашылығы, бірінші кезекте, интерактивтілік компонентінің болуымен байланысты. Мұндай кешен көбінесе қашықтықтан оқытуды ұйымдастыру үшін қолданылады, бірақ оқытудың стандартты нысандарында жүзеге асырылуы мүмкін: күндізгі, кешкі, сырттай, экстернат.

Мақалада білім беру үдерісінде ақпараттық технологияларды қолдану мәселелері зерттеледі. Оқыту құралына жататын, оқытушыға тиісті курс бойынша сабақ өткізуге көмектесетін немесе оның қызметін толық алмастыратын электрондық білім беру ресурсының сипаттамасы берілген. Мұндай кешенді студенттердің теориялық материалдарды зерттеу бойынша өзіндік жұмысын ұйымдастыру үшін, практикалық және семинарлық сабақтарды ұйымдастыру, бақылау және өзін-өзі бақылау үшін пайдалануға болады. Мақалада заманауи ақпараттық технологияларды кеңінен қолдана отырып, арнайы пәндерді 
оқытудың бірыңғай әдістемесін қалыптастыруға негізделген электрондық білім беру ресурстарының (ЭБР) мазмұнын жобалаудың жалпыланған тәсілі сипатталған. Сондай-ақ электрондық оқытудың авторлық жобаларын жобалау және әзірлеу бойынша педагогтардың сұрауларына практикалық бағытталған білім беру жүйесі қызметкерлерінің біліктілігін арттырудың авторлық бағдарламасын іске асыру нәтижелері және кәсіби педагогтардың көпфункционалды виртуалды қауымдастығының аймақтық ақпараттық-білім беру ортасын қалыптастыру талданады.

Түйін сөздер: электрондық білім беру ресурстары, электрондық білім беру ресурстарын жобалау, контентті қалыптастыру, контент нысандарын визуализациялау, білім беру, ақпарат.

\title{
Ш.А. Наубетова ${ }^{1}$, А.И. Туганбаев ${ }^{1}$, Ж.Ш. Узденбаев ${ }^{2}$ А.Ж. Аяганова ${ }^{1}$, Р.Н. Кантаева ${ }^{1}$
}

\author{
${ }^{1}$ Академия экономики и права имени У.А. Джолдасбекова, Талдыкорган, Казахстан; \\ ${ }^{2}$ Жетысуский государственный университет им. И. Жансугурова, Талдыкорган, Казахстан
}

\section{ОСОБЕННОСТИ ПРОЕКТИРОВАНИЯ ЭЛЕКТРОННЫХ ОБРАЗОВАТЕЛЬНЫХ РЕСУРСОВ}

Аннотация. Постоянные изменения, происходящие в жизни современного информационного общества, должны находить адекватное и незамедлительное отражение как в самом учебном процессе, так и в различных учебных материалах. Одним из возможных выходов из сложившейся ситуации может являться разработка электронных средств обучения практически по всем дисциплинам и их публикация в мировых телекоммуникационных сетях или на информационных носителях, предоставляющих возможность несложного оперативного тиражирования. Данное утверждение основано, в первую очередь, на возможности динамического изменения и дополнения содержания электронных средств обучения в соответствии с текущими изменениями в жизни общества, науке, культуре и пр. Кроме того, практическая работа обучаемых с информацией, представленной в электронном виде, сыграет положительную роль в общем ознакомлении будущих специалистов с компьютерными и телекоммуникационными технологиями. Стремительное развитие информационных технологий вызвало волну интереса к компьютерному обучению, но качество и эффективность разрабатываемых обучающих программ остается на низком уровне. Например, по данным американских специалистов, свыше $80 \%$ обучающих программ не удовлетворяют педагогическим требованиям. По другим данным, как свидетельствуют зарубежные и отечественные педагогические исследования, 90\% разрабатываемых программных средств для образования являются непригодными для использования в связи с их несоответствием, предъявляемым психолого-педагогическим и др. требованиям. Следует отметить низкое качество учебных программных продуктов, разработанных различными коммерческими фирмами. Так, в Германии, например, из 4000 программных средств только 80, т.е. только $2 \%$ отвечают минимальным критериям качества. Современный образовательный процесс трудно представить без качественного обеспечения учебными электронными материалами. За последнее время их видовой состав пополнился такими новейшими педагогическими программными средствами, как электронные учебные пособия, средства компьютерного моделирования, Интернет-сайты, тренажеры, обучающие программы и другие образовательные ресурсы.

В статье рассматривается значение эффективности использования электронных образовательных ресурсов в сфере образования и науки Республики Казахстан. Электронный образовательный ресурс (ЭОР) представляет собой средство обучения, помогающее преподавателю в проведении занятий по соответствующему курсу или полностью заменяющее его деятельность. Возможно применение подобного комплекса для организации самостоятельной работы учащихся по изучению теоретического материала, для организации практических и семинарских занятий, контроля и самоконтроля. ЭОР создается для определенного курса в соответствии с требованиями государственного образовательного стандарта. В его состав могут входить разнообразные программные средства, начиная от текстовых документов с иллюстративным материалом и гиперссылками, заканчивая эмуляторами лабораторных установок. В самом общем случае к электронным образовательным ресурсам относят учебные видеофильмы и звукозаписи, для воспроизведения которых достаточно бытового магнитофона или CD-плеера. Наиболее современные и эффективные в области использования в образовательном процессе электронные образовательные ресурсы воспроизводятся на компьютере. Поэтому содержание данного дистанционного курса посвящено описанию сущностных характеристик и возможностей применения вышеуказанных ресурсов в системе общего образования. Принципиальным различием электронных образовательных ресурсов от цифровых образовательных ресурсов (ЦОР) является наличие в первом случае компонента интерактивности. Такой комплекс чаще всего применяется для организации дистанционного обучения, но может быть реализован в стандартных формах обучения: очной, вечерней, заочной, экстерната. 
В статье исследуются проблемы применения информационных технологий в образовательном процессе. Дана характеристика электронного образовательного ресурса, являющегося средством обучения, помогающим преподавателю в проведении занятий по соответствующему курсу или полностью заменяющим его деятельность. Такой комплекс можно использовать для организации самостоятельной работы студентов по изучению теоретического материала, для организации практических и семинарских занятий, контроля и самоконтроля. В статье описан обобщенный подход к проектированию содержания электронных образовательных ресурсов (ЭОР), основанный на формировании единой методики преподавания специальных дисциплин, с широким использованием современных информационных технологий. В статье анализируются результаты реализации авторской программы повышения квалификации работников системы образования, обладающей практической направленностью на запросы педагогов по проектированию и разработке авторских проектов электронного обучения и формирование региональной информационнообразовательной среды многофункционального виртуального сообщества педагогов-профессионалов.

Ключевые слова: электронные образовательные ресурсы, проектирование электронных образовательных ресурсов, формирование контента, визуализация объектов контента, образование, информация.

Information about authors:

Naubetova Sh.A. Candidate of economic sciences. Academy of economics and law named after U.A. Dzholdasbekov. Taldykorgan, Republic of Kazakhstan. Shuga.naubetova@bk.ru, https://orcid.org/0000-0002-6464-4476;

Tuganbayev A.I. Master of sciences. Academy of economics and law named after U.A. Dzholdasbekov. Taldykorgan, Republic of Kazakhstan. arman.tuganbayev@bk.ru, https://orcid.org/0000-0001-7452-4868;

Uzdenbaev J.Sh. Candidate of technical sciences. Zhetysu State University n.a. I. Zhansugurov. Taldykorgan, Republic of Kazakhstan. Jorajorin@mail.ru, https://orcid.org/0000-0002-2173-8421;

Ayaganova A.J. Master of sciences. Academy of economics and law named after U.A. Dzholdasbekov. Taldykorgan, Republic of Kazakhstan. Ayazhanayaganova@mail.ru, https://orcid.org/0000-0002-1936-511X;

Kantayeva R.N. Master of sciences. Academy of economics and law named after U.A. Dzholdasbekov. Taldykorgan, Republic of Kazakhstan. ramziya.kantayeva@bk.ru, https://orcid.org/0000-0001-5513-5429;

\section{REFERENCES}

[1] Development tool for distance learning courses. (2016). http://www.ict.edu.ru/

[2] Guidelines for creating a distance learning course via the Internet.(2017). www.vita-centr.ru

[3] Gura V.V. (2007). Theoretical principles of pedagogical projecting of personality-oriented e-learning resources and environments: abstract. dis.....Dr.PED.Sciences/V. V. Gura. Rostov n/D, p. 45.

[4] Krasnov G. A. (2012).Technology of creating e-learning products/G. A. Krasnov, A. V. Solovov and M. I. Belyaev. M.: MGIU, 202 p.

[5] Methodical recommendations on creation of distance learning courses. (2017). http://www.curator.ru/method.html

[6] Norenkov I.P. (2005). Educational environment on the basis of the ontological approach/I. P. Norenkov, M. Yu Uvarov// Internet portals: content and technology: collection of scientific works.St./ redkol.: A. N. Tikhonov (pred.) [et al.]; FGU GNII ITT "Informika". - M.: Education, Vol.3.

[7] Osin A.V. (2014). Multimedia in education: the context of Informatization/ A. V. Osin. M.: Publishing service. P.27-31.

[8] Radchenko A. K.(2003). Design technology technical studies: proc.manual/A. K. Radchenko. Minsk: p.112.

[9] Samples P. I. (2004). Didactics of higher school: studies.manual/P. I. Obraztsov, V. M. Coshin. Eagle: Academy of special communication, p.24.

[10]Zainutdinova L. H. (1999). Creation and application of electronic textbooks (for example, technical disciplines): monograph/ L. H. Zaynutdinova. Astrakhan: CINTEP, p.74.

[11] Gussenova M., Gussenova S. (2019). Innovative educational technology in higher education and the creation of information educational environment using elements of the updated education in the training of competitive specialists of new formation. N e w s of the national Academy of sciences of the Republic of Kazakhstan. Series of social and human sciences. Volume 5, Number 327 (2019), 156 - 160.

[12] Gussenova M. (2019). Pedagogical bases of formation of professional competence of future teachers of foreign languages (english) with use of innovative technologies and elements of the updated education. $\mathrm{N}$ e w s of the national Academy of sciences of the Republic of Kazakhstan. Series of social and human sciences. Volume 5, Number 327 (2019), 103 - 107.

[13] Gussenova S. (2019). Creation of information and educational environment in educational institutions as a condition for achieving a new quality of education. $\mathrm{N}$ e w s of the national Academy of sciences of the Republic of Kazakhstan. Series of social and human sciences. Volume 5, Number 327 (2019), 108-112. 


\title{
PUBLICATION ETHICS AND PUBLICATION MALPRACTICE IN THE JOURNALS OF THE NATIONAL ACADEMY OF SCIENCES OF THE REPUBLIC OF KAZAKHSTAN
}

For information on Ethics in publishing and Ethical guidelines for journal publication see http://www.elsevier.com/publishingethics and http://www.elsevier.com/journal-authors/ethics.

Submission of an article to the National Academy of Sciences of the Republic of Kazakhstan implies that the work described has not been published previously (except in the form of an abstract or as part of a published lecture or academic thesis or as an electronic preprint, see http://www.elsevier.com/postingpolicy), that it is not under consideration for publication elsewhere, that its publication is approved by all authors and tacitly or explicitly by the responsible authorities where the work was carried out, and that, if accepted, it will not be published elsewhere in the same form, in English or in any other language, including electronically without the written consent of the copyrightholder. In particular, translations into English of papers already published in another language are not accepted.

No other forms of scientific misconduct are allowed, such as plagiarism, falsification, fraudulent data, incorrect interpretation of other works, incorrect citations, etc. The National Academy of Sciences of the Republic of Kazakhstan follows the Code of Conduct of the Committee on Publication Ethics (COPE), and follows the COPE Flowcharts for Resolving Cases of Suspected Misconduct (http://publicationethics.org/files/u2/New_Code.pdf). To verify originality, your article may be checked by the originality detection service Cross Check http://www.elsevier.com/editors/plagdetect.

The authors are obliged to participate in peer review process and be ready to provide corrections, clarifications, retractions and apologies when needed. All authors of a paper should have significantly contributed to the research.

The reviewers should provide objective judgments and should point out relevant published works which are not yet cited. Reviewed articles should be treated confidentially. The reviewers will be chosen in such a way that there is no conflict of interests with respect to the research, the authors and/or the research funders.

The editors have complete responsibility and authority to reject or accept a paper, and they will only accept a paper when reasonably certain. They will preserve anonymity of reviewers and promote publication of corrections, clarifications, retractions and apologies when needed. The acceptance of a paper automatically implies the copyright transfer to the National Academy of sciences of the Republic of Kazakhstan.

The Editorial Board of the National Academy of sciences of the Republic of Kazakhstan will monitor and safeguard publishing ethics.

Правила оформления статьи для публикации в журнале смотреть на сайте:

\author{
www:nauka-nanrk.kz \\ http://soc-human.kz/index.php/en/arhiv \\ Редакторы: М. С. Ахметова, Г. Б. Халидуллаева, Д. С. Аленов \\ Верстка на компьютере А.М. Кульгинбаевой \\ Подписано в печать 19.03..2020 \\ Формат 60x881/8. Бумага офсетная. Печать - ризограф. \\ 14 п.л. Тираж 500. Заказ 2.
}

Национальная академия наук $Р К$

050010, Алматы, ул. Шевченко, 28, т. 272-13-18, 272-13-19 